\title{
Intravenous calcium infusion in a calving protocol disrupts calcium homeostasis compared with an oral calcium supplement
}

\author{
Juliette Wilms, ${ }^{*}$ Guanlin Wang, John Doelman, Marc Jacobs, and Javier Martín-Tereso \\ Trouw Nutrition Research and Development, PO Box 299, 3800 AG, Amersfoort, the Netherlands
}

\section{ABSTRACT}

Hypocalcemia is a common postpartum condition in dairy cows, which negatively affects health and production. Intravenous Ca infusions are commonly included in calving protocols to prevent or mitigate the effect of hypocalcemia in multiparous cows. Thus, we sought to contrast the effect of intravenous Ca infusion against voluntary oral $\mathrm{Ca}$ intake on $\mathrm{Ca}$ metabolism. Serum total $\mathrm{Ca}(\mathrm{tCa})$ and whole-blood ionized $\mathrm{Ca}(\mathrm{iCa})$ were monitored in 24 multiparous Holstein cows after parturition. Precalving diets were formulated with a positive dietary cation-anion difference of $172 \mathrm{mEq} / \mathrm{kg}$ of $\mathrm{DM}$ and contained $4.1 \mathrm{~g}$ of $\mathrm{Ca} / \mathrm{kg}$ of DM. At parturition, cows were blocked by calving sequence and calcemic status as either normocalcemic (cutoff threshold of iCa $\geq 1.10 \mathrm{mmol} / \mathrm{L}$ ) or hypocalcemic (cutoff threshold of $\mathrm{iCa}<1.10 \mathrm{mmol} / \mathrm{L}$ ). Cows in each block were randomly assigned to 1 of 2 treatments: either an oral source of $\mathrm{Ca}$ (Ca-Oral; $\mathrm{n}=12$ ) or an intravenous source of $\mathrm{Ca}(\mathrm{Ca}-\mathrm{IV} ; \mathrm{n}=12)$. Cows in the Ca-Oral group were offered a 20-L commercial Ca suspension (48 g of Ca) for voluntary consumption. The supplement contained $\mathrm{Ca}$ carbonate, $\mathrm{Ca}$ formate, $\mathrm{Ca}$ propionate, and other minerals and vitamins (Farm-O-San Reviva, Trouw Nutrition, Amersfoort, the Netherlands). Cows in the Ca-IV group received a $450-\mathrm{mL}$ intravenous Ca solution $(13 \mathrm{~g}$ of $\mathrm{Ca}$ ) that contained $298 \mathrm{mg} / \mathrm{mL}$ of $\mathrm{Ca}$ gluconate, $33 \mathrm{mg} / \mathrm{mL}$ of magnesium chloride, and 82 $\mathrm{mg} / \mathrm{mL}$ of boric acid (AmosCAL, Kommer-Biopharm BV, Heiloo, the Netherlands). Both treatments were initiated within $25 \pm 10 \mathrm{~min}$ after calving. The oral Ca suspension was offered to cows in a $25-\mathrm{L}$ bucket and was available for $10 \mathrm{~min}$. All cows in the Ca-Oral group voluntarily consumed the entire $20 \mathrm{~L}$ of the Ca suspension within 5 min. Blood samples for Ca analyses were collected at 0 (before treatment initiation), 1, 3, 10, and $18 \mathrm{~h}$ relative to treatment, and at 0700 and 1900 $\mathrm{h}$ for the next 2 consecutive days, to represent the 24-,

Received September 26, 2018.

Accepted March 12, 2019

*Corresponding author: juliette.wilms@trouwnutrition.com
36-, 48-, and 60-h sampling time points. In Ca-IV cows, both $\mathrm{iCa}$ and tCa concentrations peaked at $1 \mathrm{~h}(1.54$ $\mathrm{mmol} / \mathrm{L}$ for iCa and $2.85 \mathrm{mmol} / \mathrm{L}$ for tCa) and declined to a nadir at $24 \mathrm{~h}$ following treatment initiation (0.94 $\mathrm{mmol} / \mathrm{L}$ for $\mathrm{iCa}$ and $1.74 \mathrm{mmol} / \mathrm{L}$ for tCa). Although whole-blood $\mathrm{iCa}$ and serum tCa were higher at 1 and 3 $\mathrm{h}$ in Ca-IV cows, concentrations of iCa were greater for Ca-Oral cows at 18, 24, and $36 \mathrm{~h}$ and for tCa at 24 and $36 \mathrm{~h}$. Our data indicate that intravenous $\mathrm{Ca}$ infusion immediately induced a state of hypercalcemia followed by lower whole-blood iCa and serum tCa concentrations $24 \mathrm{~h}$ later compared with oral $\mathrm{Ca}$.

Key words: subclinical hypocalcemia, calcium supply, dairy cow

\section{INTRODUCTION}

The selection of dairy cows with high genetic merit for milk production has increased milk yields to several times greater than the requirements of the offspring, creating a discontinuity between Ca demand for fetal growth and that for milk production immediately after calving (Ramberg et al., 1984). Hypocalcemia is a common metabolic condition during the transition period, characterized by a serum total Ca (tCa) concentration below $2 \mathrm{mmol} / \mathrm{L}$ (Martín-Tereso and Martens, 2014). Although incidence of clinical hypocalcemia (tCa $<1.4$ $\mathrm{mmol} / \mathrm{L}$ ) is rather rare in modern production systems, subclinical hypocalcemia affects between 41 and $54 \%$ of multiparous cows (Reinhardt et al., 2011). Cows with subclinical hypocalcemia are at a greater risk for calving-related disorders (Chapinal et al., 2011; Martinez et al., 2012) and culling (Roberts et al., 2012). Short-term postpartum management strategies to prevent or treat hypocalcemia are often integrated in farm protocols and include Ca boluses (Sampson et al., 2009), drenches (Goff and Horst, 1993), or voluntarily consumed oral Ca supplements (Geishauser et al., 2008), as well as subcutaneous (Goff, 1999) or i.v. infusions (Blanc et al., 2014). These practices represent a therapeutic intervention more than a prevention strategy, and the implications of these strategies for metabolism and health require consideration. 
Clinical hypocalcemia is usually treated by i.v. administration of 8 to $12 \mathrm{~g}$ of Ca (Goff, 1999). Treating cows with i.v. Ca infusions is the most direct intervention method to correct hypocalcemia and is understood to be an easy and inexpensive solution, although it may delay the adaptation of Ca metabolism, even inducing hypocalcemia in initially healthy animals (Martín-Tereso and Martens, 2014; Blanc et al., 2014). Intravenous $\mathrm{Ca}(11 \mathrm{~g}$ of $\mathrm{Ca})$ is therefore not recommended for treating cows that are still standing (Oetzel, 2011). Blanc et al. (2014) demonstrated that administration of i.v. Ca infusions ( $11 \mathrm{~g}$ of $\mathrm{Ca}$ ) to dairy cows at calving resulted in fluctuations of serum tCa concentration that could be detrimental, as the initial stage of hypercalcemia was followed by hypocalcemia $24 \mathrm{~h}$ later. The authors demonstrated that unlike i.v. Ca infusion, provision of an oral source of $\mathrm{Ca}\left(43 \mathrm{~g}\right.$ of $\mathrm{Ca}$ from $\mathrm{CaCl}_{2}$ and $\mathrm{CaSO}_{4}$ ) immediately after calving proved to sustain serum tCa concentration.

In contrast to i.v. Ca infusions, providing oral $\mathrm{Ca}$ supplements as a drench or as a palatable drink is unlikely to result in delayed regulation consequent to a positive calcemia signal (Goff, 1999), except when a high dose (100 g; Goff and Horst, 1993; Oetzel, 2013) or multiple doses are administered (Valldecabres et al., 2018). $\mathrm{CaCl}_{2}$ is the most common source of $\mathrm{Ca}$ in oral Ca supplements and can result in epithelial damage during administration (Thilsing-Hansen et al., 2002). Unlike $\mathrm{CaCl}_{2}, \mathrm{CaCO}_{3}$ does not represent a risk of irritation to the mucous lining of the gastrointestinal tract. Furthermore, $\mathrm{CaCO}_{3}$ suspensions offer the possibility of avoiding drenching, as they are not systematically rejected by the animals. Therefore, $\mathrm{CaCO}_{3}$ formulations allow for less-invasive oral administration, potentially improving animal-welfare aspects of the calving protocol. Despite Goff and Horst (1993) having shown a short-term increase in serum tCa within $3 \mathrm{~h}$ after administration of $\mathrm{CaCl}_{2}(50 \mathrm{~g}$ of $\mathrm{Ca})$, the transient nature of this effect indicates that $\mathrm{Ca}$ ions precipitate at high$\mathrm{pH}$ and high-carbonate concentrations in the rumen (Martín-Tereso and Martens, 2014). This likely results in a similar availability of Ca supply, between $\mathrm{CaCO}_{3}$ and $\mathrm{CaCl}_{2}$ formulations, beyond the transient positive calcemic signal. In fact, it could be proposed that as the rate of passage to lower gastrointestinal compartments delays the release of ruminal contents into the abomasum and duodenum to a small percentage per hour, availability for passive absorption of $\mathrm{Ca}$ from $\mathrm{CaCO}_{3}$ may therefore be moderate and extended in time (Martín-Tereso and Martens, 2014). Fowers et al. (2015) showed that a suspension containing $\mathrm{CaCO}_{3}$ (48 $\mathrm{g}$ of $\mathrm{Ca}$ ), voluntarily consumed within $5 \mathrm{~min}$, was able to elevate serum tCa concentration when compared with a control of warm water. Geishauser et al. (2008) also demonstrated the palatability of a Ca suspension ( $80 \mathrm{~g}$ of Ca from Ca lactate), voluntarily consumed within 2 min, as well as its ability to elevate whole-blood ionized $\mathrm{Ca}(\mathbf{i C a})$ concentration. In this light, our objective was to contrast the effect of providing an intravenous source of Ca against voluntary oral Ca in dairy cows immediately after calving on Ca metabolism, mineral balance, and metabolic parameters in multiparous dairy cows.

\section{MATERIALS AND METHODS}

This study was conducted between July and December 2016 at the Trouw Nutrition Dairy Research Facility (Boxmeer, the Netherlands). All procedures described in this article complied with the Dutch Law on Experimental Animals, which complies with ETS123 (Council of Europe 1985 and the 86/609/EEC Directive) and were approved by the animal welfare authority (DEC Utrecht, the Netherlands).

\section{Animals and Experimental Design}

The experiment was carried out in a complete randomized block design. Between July and December 2016, 24 Holstein Friesian cows were enrolled in the study for a duration of $6 \mathrm{wk}$ per cow (3 wk prepartum and $3 \mathrm{wk}$ postpartum). Selection criteria for enrollment included parity (entering second or greater lactation), apparent health before parturition, and absence of clinical hypocalcemia with recumbency after calving (Oetzel, 1988). Cows that calved consecutively and that were similar in calcemic status at calving were considered a block, upon which treatments were randomized. Calcemic status at treatment initiation was defined as normocalcemic (threshold cutoff of iCa $\geq 1.10 \mathrm{mmol} / \mathrm{L}$ ) or hypocalcemic (threshold cutoff of iCa $<1.10 \mathrm{mmol} / \mathrm{L}$ ), in a similar approach to that described by Blanc et al. (2014). Cows in each block were randomly assigned to 2 treatments: either an oral source of $\mathrm{Ca}$ (Ca-Oral; $\mathrm{n}=12)$ or an intravenous source of $\mathrm{Ca}(\mathbf{C a}-\mathbf{I V}$; $\mathrm{n}$ $=12$ ). Cows in the Ca-Oral group were individually offered a 20-L commercial Ca suspension (47.7 g of Ca) for voluntary consumption. The supplement contained $\mathrm{Ca}$ carbonate, $\mathrm{Ca}$ formate, Ca propionate, and other minerals and vitamins (Farm-O-San Reviva, Trouw Nutrition, Amersfoort, the Netherlands). The Ca suspension was prepared in a 25 -L bucket containing $10 \mathrm{~L}$ of warm water $\left(40\right.$ to $\left.45^{\circ} \mathrm{C}\right)$. Once dissolved, $10 \mathrm{~L}$ of cold water was added, to achieve a drinking temperature of 25 to $30^{\circ} \mathrm{C}$. Administration of the Ca suspension was always supervised to prevent any other cow from drinking the solution. The bucket was placed in front of the cow within 35 min after parturition. Cows were allowed to consume the Ca suspension for 10 
min, after which eventual leftovers would be weighed. The Ca suspension was offered once only and was never drenched. Cows in the Ca-IV group received a $450-\mathrm{mL}$ intravenous $\mathrm{Ca}$ solution (12.5 $\mathrm{g}$ of $\mathrm{Ca}$ ) that contained $298.4 \mathrm{mg} / \mathrm{mL}$ of Ca gluconate, $33.3 \mathrm{mg} / \mathrm{mL}$ of magnesium chloride, and $82 \mathrm{mg} / \mathrm{mL}$ of boric acid (AmosCAL, Kommer-Biopharm BV, Heiloo, the Netherlands). The Ca-IV infusion was administered only once through the jugular vein, within $35 \mathrm{~min}$ after parturition. Ad libitum water was available through the usual drinking system present in the calving pen, including during treatment administration.

\section{Housing and Herd Management}

Three weeks before the expected calving date, cows were moved into the close-up group in a freestall setting. At the first signs of calving, cows were transferred to a straw-bedded group calving pen $\left(32 \mathrm{~m}^{2}\right)$. Cows stayed in the calving pen at least $48 \mathrm{~h}$ following parturition and from there were moved to the adjacent lactation group. The lactating dairy herd at the dairy research facility (approximately 110 cows), was housed in a freestall barn. Stalls were lined with rubber mattresses and bedded with wood shavings. Cows were milked twice daily at 0500 and $1630 \mathrm{~h}$.

\section{Diets and Feeding}

The estimated DMI used to formulate rations was $14.0 \mathrm{~kg}$ for the close-up ration and $23.5 \mathrm{~kg}$ for the lactation ration. All study cows received the same close-up and fresh cow diet (Table 1). Cows were individually fed upon entry into the close-up group by means of electronic forage bins (Roughage Intake Control, Fullwood Packo, Ellesmere, UK) and out-of-parlor pelleted concentrate feeders (Concentrate Boxes, Fullwood Packo). The close-up diet was a forage mixture consisting of maize silage, barley straw, and rapeseed meal, fed ad libitum and supplemented with a compound feed allowance from an out-of-parlor electronic feeder (Table 1). The precalving diet presented a positive DCAD of $171.8 \mathrm{mEq} / \mathrm{kg}$ of $\mathrm{DM}$, as it included no anionic salts and contained $4.1 \mathrm{~g}$ of $\mathrm{Ca} / \mathrm{kg}$ of DM (Table 1). During the lactation period, the ration was composed of a forage mixture that consisted of maize and grass silage, brewer's grain, and grass hay, with supplemental compound feed from an out-of-parlor electronic feeding station (Table 1). The mixture was prepared and delivered daily, and refusals were removed from the bunks before feeding the following day. Animals had ad libitum access to water.

\section{Measurements and Sampling}

Intakes of the Ca-Oral suspension were recorded by weighing leftovers. Forages for close-up and lactating rations were analyzed every $2 \mathrm{wk}$ for DM content. Each batch of close-up compound feed was analyzed once. Additionally, samples of forages for both close-up and lactation diets were taken every $2 \mathrm{wk}$, and composites were made at the end of the study for analysis. Daily feed intake and milk yield were automatically recorded. Weekly averages were generated from daily milk production for the first 3 wk postcalving. Milk composition (lactose, fat, and protein) was determined from the standard weekly milk sampling. After calving, body weights were recorded automatically 5 times per wk (every evening), and weekly averages were calculated. Blood samples were drawn from the coccygeal vessels into 9-mL lithium heparin Vacutainers (BD Vacutainer, Franklin Lakes, NJ). One drop of blood was then in-

Table 1. Dietary ingredients and analyzed nutrient composition of pre- and postpartum diets on DM basis ${ }^{1}$

\begin{tabular}{|c|c|c|}
\hline \multirow[b]{2}{*}{ Item } & \multicolumn{2}{|c|}{ Ration composition } \\
\hline & $\begin{array}{l}\text { Prepartum } \\
\text { diet }\end{array}$ & $\begin{array}{l}\text { Postpartum } \\
\text { diet }^{2}\end{array}$ \\
\hline \multicolumn{3}{|c|}{ Ingredient composition (\% of DM) } \\
\hline Maize silage & 41.2 & 44.2 \\
\hline Barley straw & 23.1 & - \\
\hline Rapeseed meal & 19.4 & - \\
\hline Close-up compound feed & 16.3 & - \\
\hline Grass silage & - & 20.3 \\
\hline Brewers grain wet & - & 6.0 \\
\hline Grass hay & - & 5.3 \\
\hline Lactation compound feed & - & 24.2 \\
\hline \multicolumn{3}{|l|}{ Nutrient composition $^{3}$} \\
\hline $\mathrm{CP}$ & 146 & 158 \\
\hline $\mathrm{NDF}$ & 408 & 369 \\
\hline Starch & 196 & 205 \\
\hline Sugars & 47 & 41 \\
\hline $\mathrm{Ca}$ & 4.1 & 4.8 \\
\hline $\mathrm{P}$ & 4.4 & 3.4 \\
\hline $\mathrm{Mg}$ & 3.7 & 2.5 \\
\hline $\mathrm{K}$ & 13.2 & 15.9 \\
\hline $\mathrm{Na}$ & 1.1 & 1.8 \\
\hline $\mathrm{S}$ & 2.3 & 2.2 \\
\hline $\mathrm{Cl}$ & 2.5 & 4.4 \\
\hline $\mathrm{Fe}(\mathrm{mg} / \mathrm{kg})$ & 201.4 & 252.7 \\
\hline $\mathrm{Mn}(\mathrm{mg} / \mathrm{kg})$ & 62.8 & 59.8 \\
\hline $\mathrm{Cu}(\mathrm{mg} / \mathrm{kg})$ & 22.2 & 15.9 \\
\hline $\mathrm{Zn}(\mathrm{mg} / \mathrm{kg})$ & 75.3 & 61.0 \\
\hline $\mathrm{DCAD}^{4}(\mathrm{mEq} / \mathrm{kg})$ & +171.8 & +221.3 \\
\hline
\end{tabular}

${ }^{1}$ Nutrient composition of the ration is based on expected 14.0 and 23.5 $\mathrm{kg}$ of DMI for close-up and fresh cow diets respectively. Forage and compound feed were fed separately. Analyzed values presented in the table are the summation of all ration ingredients.

${ }^{2}$ Averaged values calculated over a period of 5 mo.

${ }^{3}$ Expressed in grams per kilograms of DM unless otherwise specified.

${ }^{4}$ Calculated using the equation $[(\mathrm{mEq}$ of $\mathrm{Na}+\mathrm{mEq}$ of $\mathrm{K})-(\mathrm{mEq}$ of $\mathrm{Cl}+\mathrm{mEq}$ of $\mathrm{S})]$. 
serted in a cartridge using a pipette and analyzed immediately using a blood gas analyzer (VetScan i-STAT 1, Abaxis, Inc., Union City, CA) to determine acid-base balance, blood chemistry, and hematology. For mineral analysis, blood samples were taken in 9-mL tubes with anticoagulant (BD Vacutainer). Tubes with anticoagulant were set for $15 \mathrm{~min}$ and centrifuged at 1,500 $\times$ $g$ for $15 \mathrm{~min}$ at $20^{\circ} \mathrm{C}$. Samples were stored in $1.5-\mathrm{mL}$ serum cryotubes at $-18^{\circ} \mathrm{C}$. Samples were collected before treatment initiation $(0 \mathrm{~h})$ and at $1,3,10$, and $18 \mathrm{~h}$ post-treatment, and at 0700 and $1900 \mathrm{~h}$ for the next 2 consecutive days to represent the 24-, 36-, 48-, and 60-h sampling time points. For Ca-Oral, the time relative to treatment was measured from the time at which cows drank the complete solution.

\section{Chemical Analysis}

Feed samples were processed and analyzed at Masterlab (Boxmeer, the Netherlands). Milk samples were analyzed by Qlip (Zutphen, the Netherlands). Dry matter content was determined after drying for $4 \mathrm{~h}$ at $103^{\circ} \mathrm{C}$ (EC 152/2009; EC, 2009). Mineral content of feed was digested with an ash method, including an oven step with different temperature programs, for $13 \mathrm{~h}$. Then, $\mathrm{HCl}$ was added to make a clear solution, and the solution was dissolved in a volume flask. This was analyzed using inductively coupled plasma mass spectrometry (ICP-MS 300D/350D with auto sampler, Perkin Elmer, Waltham, MA). The ICP-MS measurement was performed according to NEN-EN 15510 (EU, 2017). Chloride from feed was analyzed by a colorimetric analyses based on the improved Fried method, using mercuric 2,4,6-tripyridyl-s-triazine (DICL-250, BioAssay Systems, Hayward, CA). Crude protein was determined according to the Dumas principle (ISO 16634-1; ISO, 2008). Crude fat was determined by treating the sample with hydrochloric acid and subsequently extracting with petroleum (EC 152/2009; EC, 2009). Amylase-treated NDF was determined using heat-stable $\alpha$-amylase and expressed without residual ash (ISO 16472; ISO, 2006). Starch was determined enzymatically using amyloglucosidase (ISO 15914; ISO, 2004). Sugars were determined according to the LuffSchoorl method and expressed as glucose for feed and lactose for milk (71/250/EEC; EU, 1971).

Serum samples were processed at the University of Nottingham (Nottingham, UK). Elemental minerals ( $\mathrm{Na}, \mathrm{K}, \mathrm{tCa}$, and $\mathrm{Mg}$ ) were determined using inductively coupled plasma mass spectrometry (ICP-MS, Thermo Fisher XSeriesII, Thermo Fisher Scientific, Waltham, $\mathrm{MA}$ ). Serum $\mathrm{Cl}$ and serum inorganic $\mathrm{P}$ were carried on an RX Imola (Randox Laboratories, Crumlin, UK) using commercial kits (Randox Laboratories) according to the manufacturer's instructions. All analyses were run with QC material in the assay run. Blood acid-base balance ( $\mathrm{pH}, \mathrm{HCO}_{3}$, and base excess), blood chemistry (glucose and iCa), and blood hematology (hematocrit) were analyzed using a portable blood gas analyzer (VetScan i-STAT 1).

\section{Calculations and Statistical Analysis}

The study was dimensioned to detect differences in serum tCa concentration. Blanc et al. (2014) found significant differences in serum tCa $36 \mathrm{~h}$ after treatment initiation between Ca-Oral and Ca-IV with 11 cows per treatment group. Therefore we included 24 cows, 12 in each treatment group, in the current study. General linear mixed models with repeated measures were used for the analyses of blood parameters using the SAS MIXED procedure (SAS Institute, 2013). Blood results at treatment initiation were entered into the model as a baseline covariate. Parity was included as a continuous variable and was removed if it allowed a lower corrected Akaike information criterion. A corrected Akaike information criterion of at least 3 points less was deemed a more parsimonious model. Block was included as fixed effect. The heterogeneous Toeplitz covariance structure was applied to all analyzed blood variables. For production parameters, the autoregressive covariance structure was applied. To determine influential observations, we used the influence option in the MODEL statement in SAS (SAS Institute, 2013) to measure the influence of each observation on the parameter estimates. The threshold associated with Cook's distance allows for estimation and identification of influential individuals. We used the cutoff point proposed by Belsley et al. (1985) to decide whether to remove a cow from the data set. This cutoff point was set at $2 p / n$, where $n$ is the number of observations used to fit the model and $p$ is the number of parameters in the model. We then iteratively deleted influential cows from the model. This was applied to all measured parameters. Significant interactions of treatment $\times$ time were explored using the SLICE option of the LSMEANS statement of the MIXED procedure of SAS (SAS Institute, 2013). Comparisons across treatments at each significant time point were conducted with the PDIFF option of the LSMEANS statement of SAS (SAS Institute, 2013). Variables were declared significant at $P \leq 0.05$, and trends were reported when $P<0.1$.

\section{RESULTS AND DISCUSSION}

Elapsed time between calving and treatment administration was $24 \pm 11 \mathrm{~min}$ for Ca-IV cows and 25 $\pm 9 \mathrm{~min}$ for Ca-Oral cows. All cows fully consumed 
Table 2. Values (LSM) of parameters describing cows 1 wk before and immediately after treatment initiation in 24 multiparous cows

\begin{tabular}{|c|c|c|c|c|}
\hline \multirow[b]{2}{*}{ Item } & \multicolumn{2}{|c|}{ Treatment $^{1}$} & \multirow[b]{2}{*}{ Pooled SEM } & \multirow[b]{2}{*}{$P$-value } \\
\hline & Ca-Oral & $\mathrm{Ca}-\mathrm{IV}$ & & \\
\hline \multicolumn{5}{|l|}{ Before treatment initiation } \\
\hline Lactation number & 3.81 & 2.53 & 0.32 & 0.01 \\
\hline DMI at dry-off $(\mathrm{kg} / \mathrm{d})$ & 12.4 & 14.3 & 1.17 & 0.25 \\
\hline Days in close-up & 23.9 & 24.8 & 2.59 & 0.82 \\
\hline BW precalving $(\mathrm{kg})$ & 674 & 693 & 74.7 & 0.90 \\
\hline \multicolumn{5}{|l|}{ After treatment initiation } \\
\hline Colostrum production $(\mathrm{L})$ & 4.63 & 5.44 & 0.96 & 0.54 \\
\hline Brix value for colostrum (\%) & 24.2 & 24.2 & 0.82 & 0.97 \\
\hline
\end{tabular}

${ }^{1}$ Treatments were either an oral source of $\mathrm{Ca}(\mathrm{Ca}-\mathrm{Oral}, \mathrm{n}=12)$ or an intravenous source of $\mathrm{Ca}(\mathrm{Ca}-\mathrm{IV}, \mathrm{n}=12)$.

the full $20 \mathrm{~L}$ of the Ca-Oral suspension within 5 min. Therefore, Ca intake was consistent for all cows on that treatment. This supports previous results from Fowers et al. (2015), which demonstrated a high rate of voluntary consumption of the same Ca suspension. Parity of cows ranged from 2 to 6 and was higher in the Ca-Oral group $(P<0.05$; Table 2$)$, despite randomization of treatment assignment. Animal performance in the first $3 \mathrm{wk}$ of lactation are illustrated in Table 3 and did not differ between treatments. As expected, there was an effect of time on DMI, milk yield, milk composition (lactose and protein), and BW $(P<0.01)$.

\section{Calcium Metabolism}

The concentration of whole-blood iCa at calving ranged from 0.73 to $1.39 \mathrm{mmol} / \mathrm{L}$, and none of the cows displayed signs of clinical hypocalcemia. The proportion of iCa in serum tCa was $54 \%$ at calving, consistent with results described by Ballantine and Herbein (1991), where $\mathrm{iCa}$ concentration was $57 \%$ at calving. Proportion of iCa in serum tCa was higher in Ca-Oral cows $(56 \%)$ compared with Ca-IV cows $(53 \% ; P<0.01$; Table 4). For analyses of Ca dynamics in blood, 2 cows were identified as influential observations and removed from the data set. Treatment, time, and treatment $\times$ time interaction were significant for both whole-blood $\mathrm{iCa}$ and serum tCa concentrations $(P<0.01)$. The significant time $\times$ treatment interaction reflects the increase in blood Ca concentration for Ca-IV cows, with a maximum observed at $1 \mathrm{~h}$ after treatment initiation $(1.5 \mathrm{mmol} / \mathrm{L}$ for $\mathrm{iCa}$, and $2.9 \mathrm{mmol} / \mathrm{L}$ for tCa), followed by a steep decline that reached a nadir at $24 \mathrm{~h}$ following treatment initiation $(0.9 \mathrm{mmol} / \mathrm{L}$ for iCa, and $1.7 \mathrm{mmol} / \mathrm{L}$ for tCa). Cows in the Ca-IV group had higher $\mathrm{iCa}$ and tCa concentrations than the Ca-Oral cows at 1 and $3 \mathrm{~h}$ after treatment initiation $(P<0.01)$. However, compared with the Ca-Oral group, Ca-IV cows had significantly lower iCa concentrations at 18 , 24 , and $36 \mathrm{~h}$ and significantly lower tCa at $24 \mathrm{~h}(P \leq$ 0.05; Figure 1, A and B). Additionally, we observed a trend for a lower tCa at $36 \mathrm{~h}$ for Ca-IV cows $(P<0.1)$. The observed dynamics for serum tCa in Ca-IV cows are consistent with previous findings from Blanc et al. (2014) and Braun et al. (2009), where the nadir for serum tCa also occurred $24 \mathrm{~h}$ after treatment initiation.

The magnitude of the fluctuations induced by treatments was therefore higher in whole-blood iCa than in serum tCa. Due to its metabolic and physiological activity, whole-blood $\mathrm{iCa}$ is the most important fraction

Table 3. Illustration of production parameters (LSM) during the first 3 wk postpartum after treatment initiation in 24 multiparous cows

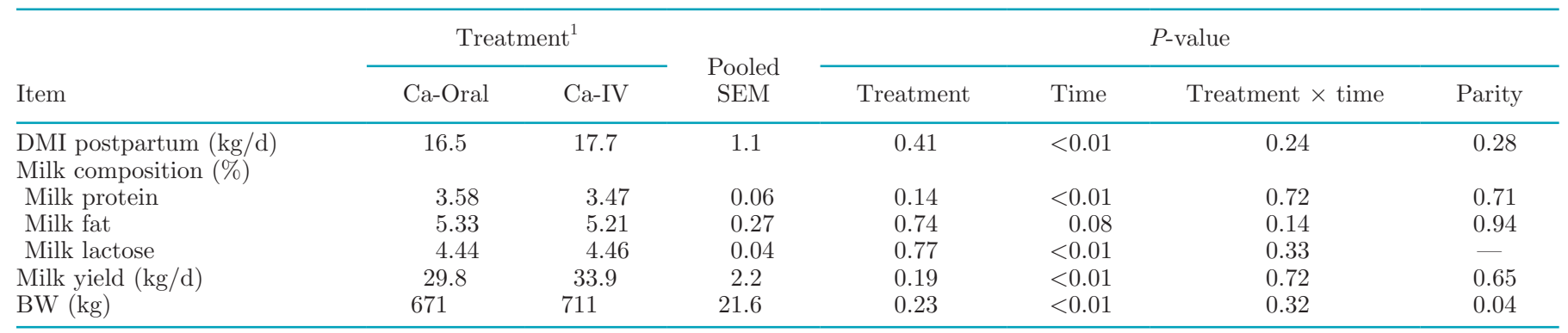

${ }^{1}$ Treatments were either an oral source of $\mathrm{Ca}(\mathrm{Ca}-\mathrm{Oral}, \mathrm{n}=12)$ or an intravenous source of $\mathrm{Ca}(\mathrm{Ca}-\mathrm{IV}, \mathrm{n}=12)$. 
in relation to hypocalcemia, as it represents the actual amount of metabolically active $\mathrm{Ca}$ in the bloodstream (Oetzel, 1988; Lincoln and Lane, 1990; Ballantine and Herbein, 1991). Therefore, even though serum tCa concentration gives an indication of Ca status, whole-blood iCa represents a better estimate of the amount of $\mathrm{Ca}$ available for uptake and utilization by tissues (Ballantine and Herbein, 1991; Schenck and Chew, 2008). In clinical situations, the animals might not be able to maintain normal concentrations of these constituents in blood, thus substantially changing the correlation between tCa and iCa concentrations (Toffaletti, 1989). Leno et al. (2017) demonstrated that the relationship between whole-blood $\mathrm{iCa}$ and serum tCa differed by sampling time point after calving. Additionally, these authors showed that $\mathrm{iCa}$ measurements were more consistently related to outcomes of neutrophil oxidative burst activity measured in vitro. Therefore, wholeblood iCa concentrations likely correlate with the clinical syndrome associated with abnormal Ca status (Lincoln and Lane, 1990; Leno et al., 2017).

In contrast to Ca-IV, Ca-Oral did not present a marked increase in blood Ca immediately after the intervention. At $36 \mathrm{~h}$ after treatment initiation, iCa concentrations for Ca-IV cows tended to be lower by $6 \%$ compared with the baseline value, whereas $\mathrm{iCa}$ concentrations were stable for Ca-Oral cows $(P=0.07)$. These results suggest that $\mathrm{Ca}-\mathrm{IV}$ was not able to sustain calcemia in comparison to Ca-Oral, as whole-blood iCa decreased below the baseline concentrations in the Ca-IV group. Calcemia is tightly regulated, and administration of i.v. Ca to animals that are not suffering from clinical hypocalcemia may alter the signaling pathways controlling calcemia. This alteration is mediated through parathyroid hormone depression, activation of renal excretion, and reduced activation rate of calcitriol, all of which will delay adaptation of gastrointestinal Ca absorption, resulting in hypocalcemia in otherwise healthy animals (Martín-Tereso and Martens, 2014). As a consequence, renal and bone Ca reabsorption is reduced, which further depletes Ca from the blood (Blanc et al., 2014). Intravenous $\mathrm{Ca}$ should therefore not be administered to all animals at calving to maintain calcemia, because this approach appears to alter the ability of cows to maintain natural Ca homeostasis postpartum (Blanc et al., 2014; Martín-Tereso and Martens, 2014).

\section{Serum Magnesium and Inorganic Phosphate}

Serum $\mathrm{Mg}$ at calving was within the normal range for cows (0.9-1.2 mmol/L; Martín-Tereso and Martens, 2014). We observed a significant treatment $(P<0.01)$ and treatment $\times$ time interaction $(P<0.01)$ for serum $\mathrm{Mg}$, which reflects the transient increase in serum $\mathrm{Mg}$ concentrations for Ca-IV cows, peaking at $1 \mathrm{~h}$ posttreatment $(1.19 \mathrm{mmol} / \mathrm{L}$; Figure 2, A), followed by a decline. This likely resulted from the $\mathrm{Mg}$ content of the Ca-IV infusion $(33.3 \mathrm{mg} / \mathrm{mL}$ of $\mathrm{MgCl})$. Beyond

Table 4. Blood minerals (LSM) after treatment initiation in 24 multiparous cows

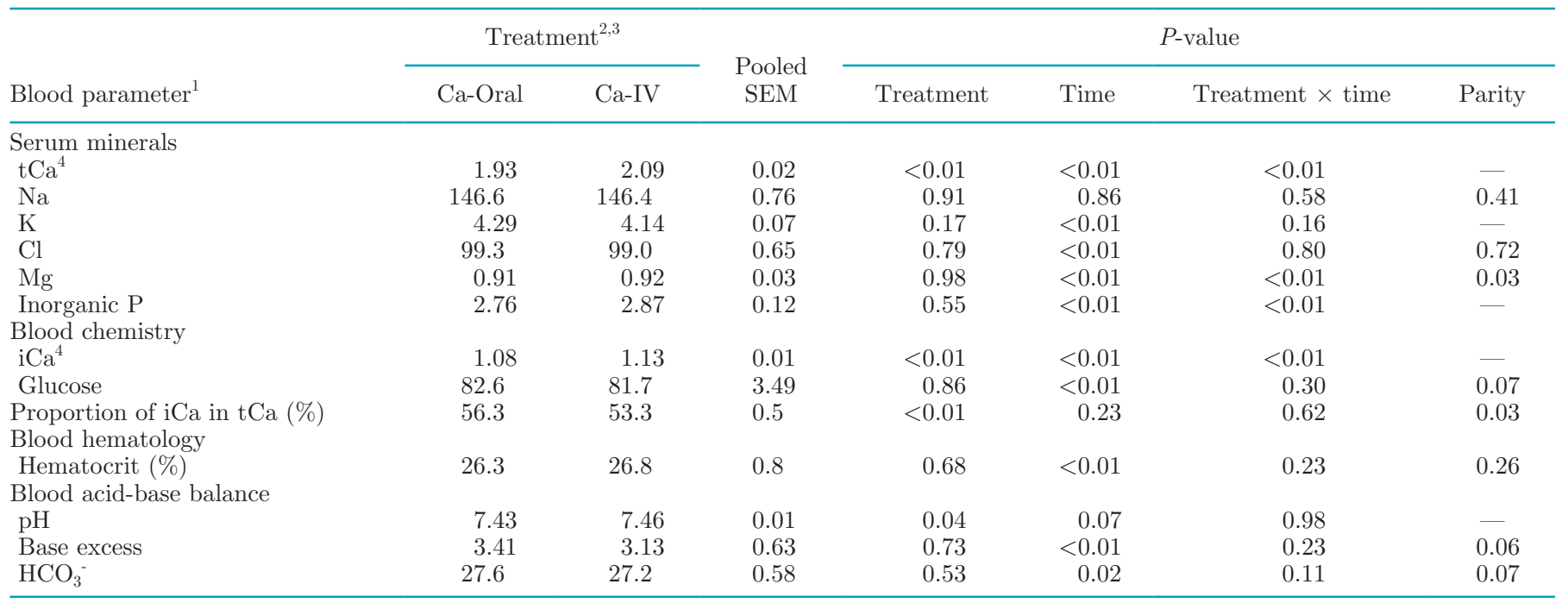

${ }^{1}$ Expressed in mmol/L unless otherwise specified.

${ }^{2}$ Treatment was either an oral source of $\mathrm{Ca}(\mathrm{Ca}-\mathrm{Oral}, \mathrm{n}=12)$ or an intravenous source of $\mathrm{Ca}(\mathrm{Ca}-\mathrm{IV}, \mathrm{n}=12)$.

${ }^{3}$ Samples were collected at 0 (before treatment initiation), 1, 3, 10, and $18 \mathrm{~h}$ relative to treatment, and at 0700 and $1900 \mathrm{~h}$ for the next two consecutive days, to represent the 24-, 36-, 48-, and 60-h sampling time points.

${ }^{4}$ Two cows, one in each treatment group, were identified as influential observations and removed from the analysis of blood Ca concentrations. 
the peak of serum $\mathrm{Mg}$ at $1 \mathrm{~h}$ after treatment initiation, there were no differences between treatment groups, suggesting that differences did not persist over time. Correction of excess serum $\mathrm{Mg}$ was likely achieved though rapid excretion via the kidney (Martín-Tereso and Martens, 2014). Cows in the current study had normal serum inorganic $\mathrm{P}$ concentrations at calving $(2.7 \mathrm{mmol} / \mathrm{L})$. Analysis revealed a significant treatment $\times$ time interaction $(P<0.05)$ for serum $\mathrm{P}$, which was higher for Ca-IV cows at 1 and $3 \mathrm{~h}$ after the treatment initiation, although differences did not persist in time (Figure 2, B).

\section{Blood Acid-Base Balance}

Blood pH was higher for Ca-IV (7.46) compared with Ca-Oral cows (7.43; Table 4). Blood base excess, which refers to the amount of base or acid needed to normalize $\mathrm{pH}$ levels, and blood $\mathrm{HCO}_{3}$ did not differ across treatment groups. A concern with the use of $\mathrm{CaCO}_{3}$ is its potential to induce an alkalogenic response (Oetzel, 2013), but this was likely not the case in the present study. However, the lack of a control treatment not receiving $\mathrm{Ca}$ at calving in the current study does not allow for a meaningful discussion on this potential effect.

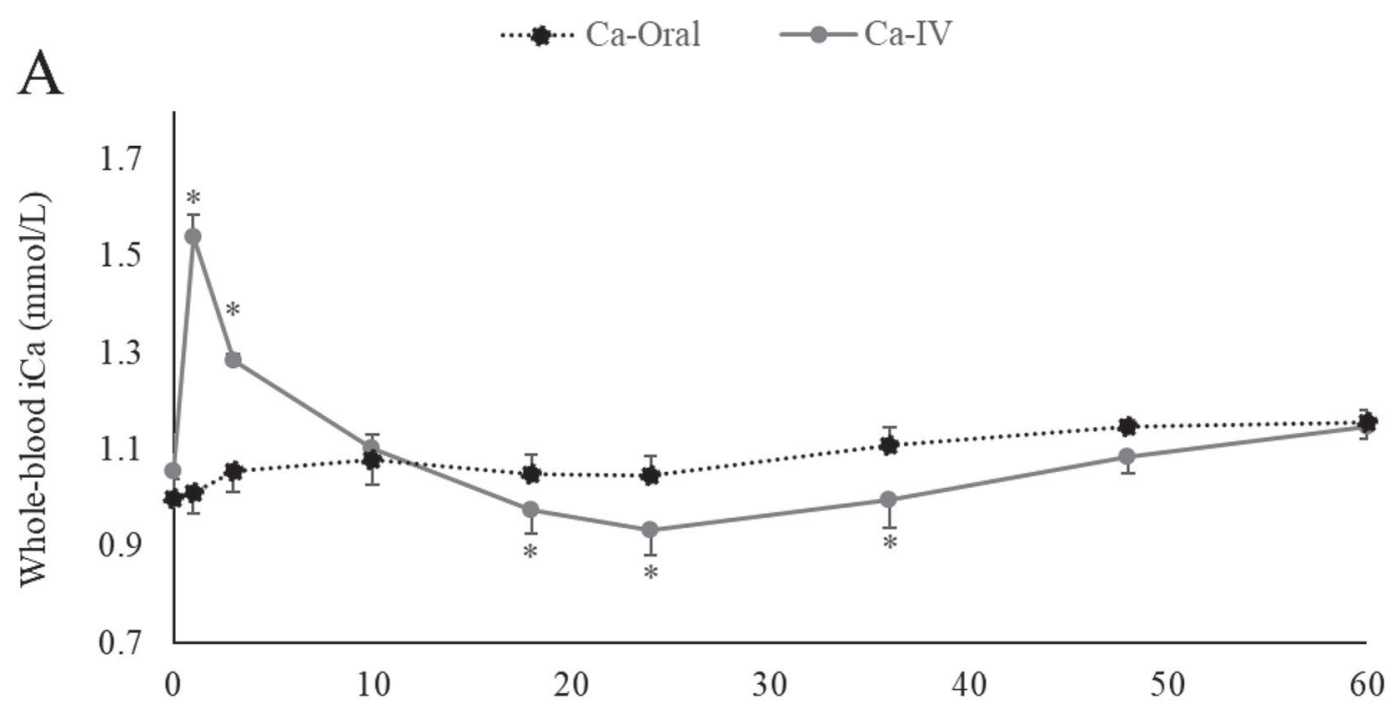

B

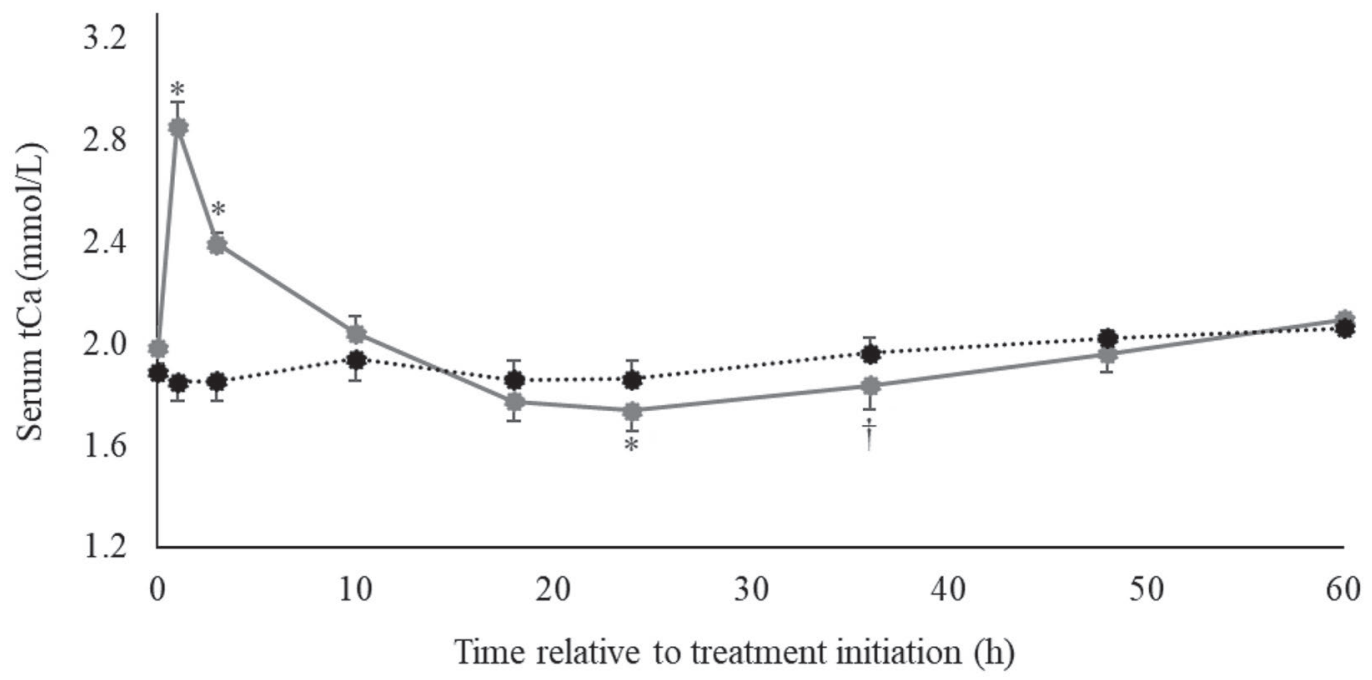

Figure 1. Blood calcium dynamics after treatment initiation in multiparous cows as shown by concentrations of ionized blood Ca (A) and total serum Ca (B). Treatment was either an intravenous source of $\mathrm{Ca}$ (Ca-IV, $\mathrm{n}=11$; one cow in each treatment group was identified as an influential observation and removed from blood Ca calculations) or an oral source of $\mathrm{Ca}$ (Ca-Oral, $\mathrm{n}=11)$. Significant treatment $\times$ time differences at each time point are indicated by $*(P \leq 0.05)$ or $\dagger(P<0.1)$. 

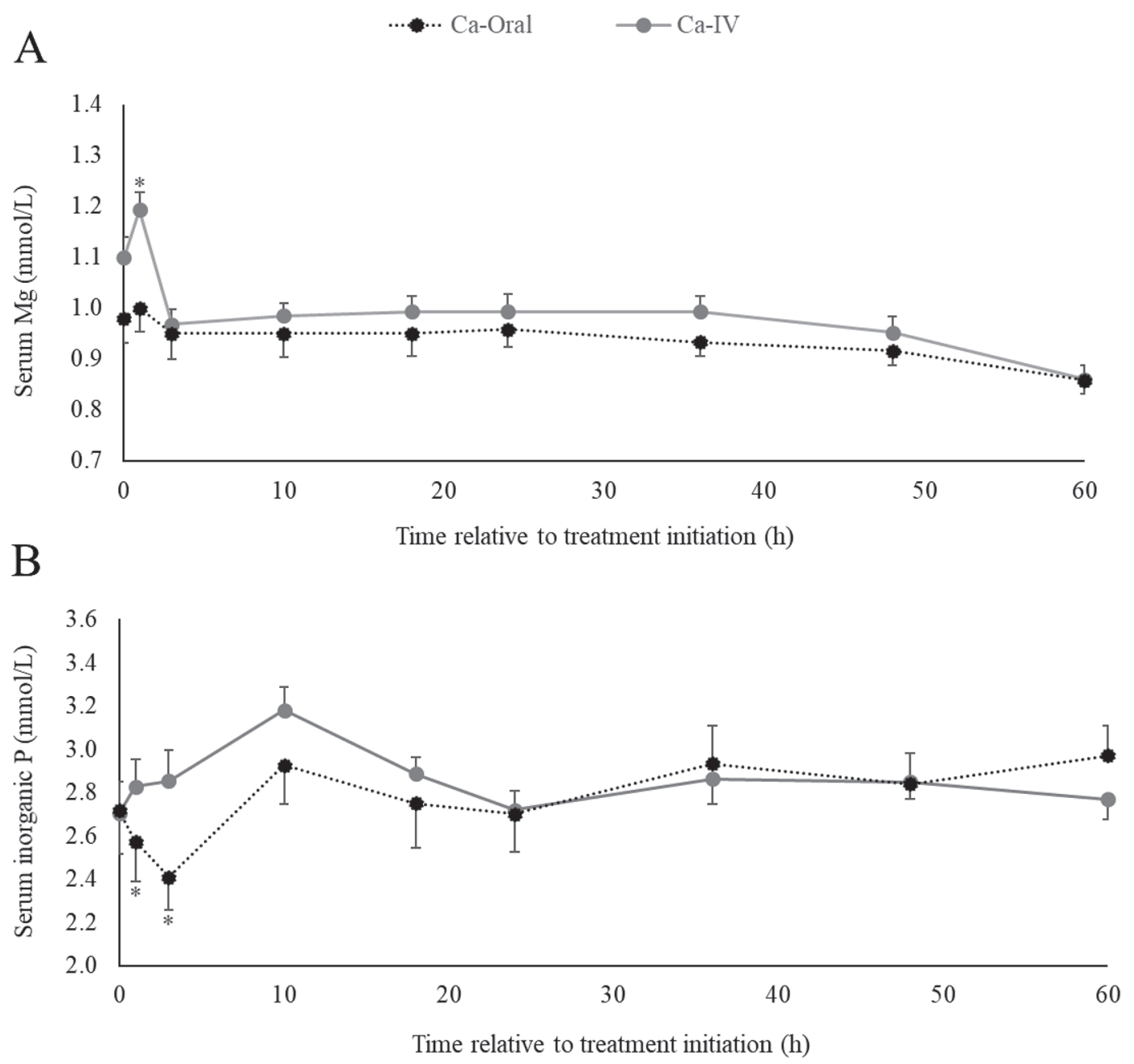

Figure 2. Concentrations of magnesium (A) and inorganic phosphate (B) after treatment initiation in multiparous cows. Treatments were either an intravenous source of $\mathrm{Ca}(\mathrm{Ca}-\mathrm{IV} ; \mathrm{n}=12)$ or an oral source of $\mathrm{Ca}(\mathrm{Ca}-\mathrm{Oral} ; \mathrm{n}=12)$. Significant treatment $\times$ time differences at each time point are indicated by $*(P<0.05)$.

Blood acid-base values remained within normal ranges, suggesting that cows were able to maintain normal acid-base balance following administration of Ca-Oral or Ca-IV (Table 4).

\section{Blood Glucose}

There was no effect of treatment on glycemia (Table 4). A transitory state of hyperglycemia was observed up to $10 \mathrm{~h}$ after treatment initiation, which peaked $1 \mathrm{~h}$ postpartum $(139 \mathrm{mmol} / \mathrm{L}$; data not shown). The effect of time was significant $(P<0.01)$. The observed transient state of hyperglycemia at calving was independent of treatment and has been previously documented in dairy cows, where a distinct transient increase in glycemia occurred at parturition (Janovick et al., 2011; Weber et al., 2016).

\section{CONCLUSIONS}

Calcium intravenous infusions at calving induced a marked increase in blood $\mathrm{Ca}$ concentration, disrupting Ca homeostasis, whereas administration of oral Ca (from $\mathrm{CaCO}_{3}$ ) did not. Intravenous Ca should therefore not be administered to all animals immediately after calving but should be restricted to severe cases of clinical hypocalcemia, when animals experience parturient paresis. Further research performed on a larger number of cows is needed to evaluate the implications of these calving protocols on health and production.

\section{ACKNOWLEDGMENTS}

The authors thank the personnel of the Trouw Nutrition Dairy research facility for their technical assistance. The authors of this paper are employed by 
Trouw Nutrition, a company with commercial interests in the oral Ca supplement included in the study.

\section{REFERENCES}

Ballantine, H. T., and J. H. Herbein. 1991. Potentiometric determination of ionized and total calcium in blood plasma of Holstein and Jersey cows. J. Dairy Sci. 74:446-449.

Belsley, D.A., E. Kuh, and R. E. Welsch. 1985. Detecting and assessing collinearity. Pages 85-191 in Regression Diagnostics: Identifying Influential Data and Sources of Collinearity. Wiley-Interscience, New York, NY.

Blanc, C. D., M. Van der List, S. S. Aly, H. A. Rossow, and N. Silvadel-Río. 2014. Blood calcium dynamics after prophylactic treatment of subclinical hypocalcemia with oral or intravenous calcium. J. Dairy Sci. 97:6901-6906.

Braun, U., P. Zulliger, A. Liesegang, U. Bleut, and M. Hässig. 2009. Effect of intravenous calcium borogluconate and sodium phosphate in cows with parturient paresis. Vet. Rec. 164:296-299.

Chapinal, N., M. Carson, T. F. Duffield, M. Capel, S. Godden, M Overton, J. E. P. Santos, and S. J. LeBlanc. 2011. The association of serum metabolites with clinical disease during the transition period. J. Dairy Sci. 94:4897-4903.

EC (European Commission). 2009. No 152/2009. Commission regulation laying down the methods of sampling and analysis for the official control of feed. Off. J. Eur. Union L 54:1-130.

EU (European Union). 1971. EEG 71/250/EEG: Methods of analysis for the official control of feeding stuffs. Off. J. Eur. Union L 155:13.

EU (European Union). 2017. NEN-EN 15510: Animal feeding stuffs: Methods of sampling and analysis-Determination of calcium, sodium, phosphorus, magnesium, potassium, iron, zinc, copper, manganese, cobalt, molybdenum and lead by ICP-AES. Off. J. Eur. Union L.

Fowers, R., A. Navarro-Villa, and J. Martín-Tereso. 2015. Effects on general health, energy status and calcium metabolism of a suspension of glucogenic precursors, vitamins and minerals supplemented to dairy cows immediately after calving. Abstract no. 47. Page 60 in Proc. 8th Int. Congr. Farm Anim. Endocrinol., Billund, Denmark. Danish Centre for Food and Agriculture. Tjele, Denmark.

Geishauser, T., S. Lechner, I. Plate, and B. Heidemann. 2008. Do cows drink calcium? Schweiz. Arch. Tierheilkd. 150:111-116.

Goff, J. P. 1999. Treatment of calcium, phosphorus, and magnesium balance disorders. Vet. Clin. North Am. Food Anim. Pract. 15:619-639.

Goff, J. P., and R. L. Horst. 1993. Oral administration of calcium salts for treatment of hypocalcemia in cattle. J. Dairy Sci. 76:101-108.

ISO. 2004. Animal feeding stuffs - Enzymatic determination of total starch content. ISO 15914:2004. International Organization for Standardization (ISO), Geneva, Switzerland.

ISO. 2006. Animal feeding stuffs - Determination of amylase-treated neutral detergent fibre content (aNDF). ISO 16472:2006. International Organization for Standardization (ISO), Geneva, Switzerland.

ISO. 2008. Food products-Determination of the total nitrogen content by combustion according to the Dumas principle and calculation of the crude protein content-Part 1: Oilseeds and animal feeding stuffs. ISO 16634-1:2008. International Organization for Standardization (ISO), Geneva, Switzerland.
Janovick, N. A., Y. R. Boisclair, and J. K. Drackley. 2011. Prepartum dietary energy intake affects metabolism and health during the periparturient period in primiparous and multiparous Holstein cows. J. Dairy Sci. 94:1385-1400.

Leno, B. M., E. M. Martens, M. J. B. Felippe, K. P. Zanzalari, J. C. Lawrence, and T. R. Overton. 2017. Short communication: Relationship between methods for measurement of serum electrolytes and the relationship between ionized and total calcium and neutrophil oxidative burst activity in early postpartum dairy cows. J. Dairy Sci. 100:9285-9293.

Lincoln, S. D., and V. M. Lane. 1990. Serum ionized calcium concentration in clinically normal dairy cattle, and changes associated with calcium abnormalities. J. Am. Vet. Med. Assoc. 197:14711474

Martín-Tereso, J., and H. Martens. 2014. Calcium and magnesium physiology and nutrition in relation to the prevention of milk fever and tetany (Dietary management of macrominerals in preventing disease). Vet. Clin. North Am. Food Anim. Pract. 30:643-670.

Martinez, N., C. A. Risco, F. S. Lima, R. S. Bisinotto, L. F. Greco, E. S. Ribeiro, F. Maunsell, K. Galvão, and J. E. P. Santos. 2012. Evaluation of peripartal calcium status, energetic profile, and neutrophil function in dairy cows at low or high risk of developing uterine disease. J. Dairy Sci. 95:7158-7172.

Oetzel, G. R. 1988. Parturient paresis and hypocalcemia in ruminant livestock. Vet. Clin. North Am. Food Anim. Pract. 4:351-364.

Oetzel, G. R. 2011. Non-infectious diseases: Milk fever. Pages 239-45 in Encyclopedia of Dairy Sciences, Vol 2. J. W. Fuquay and P. L. McSweeney, ed. Academic Press, San Diego, CA.

Oetzel, G. R. 2013. Oral calcium supplementation in peripartum dairy cows. Vet. Clin. North Am. Food Anim. Pract. 29:447-455.

Ramberg, C. F., E. K. Johnson, R. D. Fargo, and D. S. Kronfeld. 1984. Calcium homeostasis in cows, with special reference to parturient hypocalcemia. Am. J. Physiol. 246:R698-R704.

Reinhardt, T. A., J. D. Lippolis, B. J. McCluskey, J. P. Goff, and R. L. Horst. 2011. Prevalence of subclinical hypocalcemia in dairy herds. Vet. J. 188:122-124.

Roberts, T., N. Chapinal, S. J. LeBlanc, D. F. Kelton, J. Dubuc, and T. F. Duffield. 2012. Metabolic parameters in transition cows as indicators for early-lactation culling risk. J. Dairy Sci. 95:30573063.

Sampson, J. D., J. N. Spain, C. Jones, and L. Carstensen. 2009. Effects of calcium chloride and calcium sulfate in an oral bolus given as a supplement to postpartum dairy cows. Vet. Ther. 10:131-139.

SAS Institute. 2013. SAS/STAT(R) 9.4 User's Guide. SAS Institute Inc., Cary, NC.

Schenck, P. A., and D. J. Chew. 2008. Calcium: Total or ionized? Vet. Clin. North Am. Small Anim. Pract. 38:497-502.

Thilsing-Hansen, T., R. J. Jørgensen, and S. Østergaard. 2002. Milk fever control principles: A review. Acta Vet. Scand. 43:1-19. https: //doi.org/10.1186/1751-0147-43-1.

Toffaletti, J. 1989. Ionized calcium: Part I. Clin. Chem. News 15:10-11.

Valldecabres, A., J. A. A. Pires, and N. Silva-del-Río. 2018. Effect of prophylactic oral calcium supplementation on postpartum mineral status and markers of energy balance of multiparous Jersey cows. J. Dairy Sci.10144604472

Weber, C., C. T. Schäff, U. Kautzsch, S. Börner, S. Erdmann, S. Görs, M. Röntgen, H. Sauerwein, R. M. Bruckmaier, C. C. Metges, B. Kuhla, and H. M. Hammon. 2016. Insulin-dependent glucose metabolism in dairy cows with variable fat mobilization around calving. J. Dairy Sci. 99:6665-6679. 